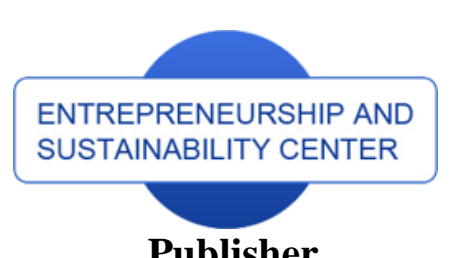

Publisher enterprise

europe

network

Business Support on Your Doorstep

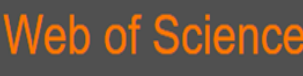

http://jssidoi.org/esc/home

Clarivate
Analytics

\title{
DIMENSIONS AND THEIR ELEMENTS AFFECTING THE INNOVATIVE ACTIVITIES OF AGRICULTURAL SMEs TOWARD THEIR SUSTAINABLE DEVELOPMENT**
}

\author{
Antonín Korauš ${ }^{1}$, Katarína Havierniková ${ }^{2}$, Miroslav Gombár ${ }^{3}$, Filip Černák ${ }^{4}$, Felcan Miroslav ${ }^{5}$ \\ ${ }^{1,5}$ Academy of the Police Force in Bratislava, Sklabinská 1, 83517 Bratislava 35, Slovak Republic \\ ${ }^{2}$ Faculty of Social and Economic Relations, Alexander Dubček University of Trenčín, Študentská 3, 91150 Trenčin, Slovakia \\ ${ }^{3,4}$ University of Prě̌ov in Prešov, Faculty of Management, Konštantínova 16, 08001 Prešov, Slovak Republic \\ E-mails: ${ }^{1}$ antonin.koraus@minv.sk ; ${ }^{2}$ katarina.haviernikova@tnuni.sk ; ${ }^{3}$ miroslav.gombar@unipo.sk ; ${ }^{4}$ fcernak@sitno.sk ; \\ [Miroslav.Felcan@minv.sk
}

Received 15 May 2020; accepted 13 October 2020; published 30 December 2020

\begin{abstract}
The vast majority of firms in each economy are small and medium-sized enterprises (SMEs) including the family business. Their sustainable development depends on the ability to implement the innovative activities. Most research studies dedicated to innovation are focused mainly on technology-based SMEs. Our paper shows the importance of innovative activities in agricultural SMEs. The main aim of this paper is to identify the key elements covered by three main dimensions (technological, non-technological, and organizational) that have an impact on innovative activities of agricultural SMEs toward their sustainable development and to investigate the perception of these elements by agricultural SMEs. The approach of this study is quantitative, based on the data gathered from 192 Slovak agricultural SMEs.
\end{abstract}

* The contribution is the result of Vega project no. 1/0194/19 "Research on process-oriented management of financial management focusing on detection of tax evasion in terms of international business".
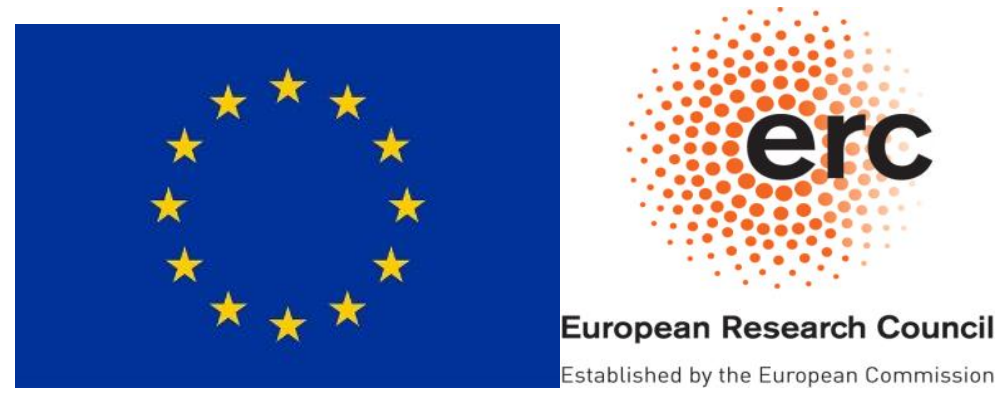


\section{ENTREPRENEURSHIP AND SUSTAINABILITY ISSUES}

ISSN 2345-0282 (online) http://jssidoi.org/jesi/

2020 Volume 8 Number 2 (December)

http://doi.org/10.9770/jesi.2020.8.2(68)

Make your research more visible, join the Twitter account of ENTREPRENEURSHIP AND SUSTAINABILITY ISSUES: @Entrepr69728810

The results pointed on the importance of all dimensions and three main elements covered each dimension. The results of this paper may help SMEs, professionals, and policymakers to better understand the importance of innovative activities in agricultural SMEs.

Keywords: SMEs; sustainable development; innovative activities; dimension; elements; policy

Reference to this paper should be made as follows: Korauš, A., Havierniková, K., Gombár, M., Černák, F., Miroslav, F. 2020. Dimensions and their elements affecting the innovative activities of agricultural SMEs toward their sustainable development. Entrepreneurship and Sustainability Issues, 8(2), 1142-1157. http://doi.org/10.9770/jesi.2020.8.2(68)

JEL Classifications: O31, L26, C12

\section{Introduction}

The significant literature and research studies focused on innovative activities in large and medium enterprises prevail the studies that report on innovative activities in micro and small enterprises (Berne et al. 2019; Raghuvanshi, et al. 2019). This paper widespread the literature sources, which suppose that innovative activities are realized also in the micro, small, medium, as well as family businesses. The innovation is pivotal mainly for entrepreneurs and affects all mechanisms related to SMEs' sustainable existence (products and technology development, the improvement of their designs, the production planning, the adoption of new technologies, marketing, sales, management activities, qualification of employees, etc.) The creation and management of innovation in SMEs is a complex process that uses new knowledge, technologies, and processes for the creation of new, as well as adapting existing products or services. The results of innovation activities bring an increase in efficiency and competitiveness, which contribute to the sustainable development of SMEs.

For the agricultural sector, the low level of innovation is typical, due to the fact, that it has been regarded as a lowtech sector, in which the innovations are accrual and are characterized by a low degree of newness (Ciliberti et al. 2016). If the agricultural SMEs realize the innovation activities, they concern the exploitation of new ideas to produce new products, processes, services, or business practices (Caiazza et al. 2016). Various studies reported that there is a gap between the accepted theories and practices in innovation management in the case of agricultural SMEs. We can find differences in understanding, implementing, and measuring of innovative activities in the SMEs (Faherty \& Stephens, 2016). The agricultural SMEs are also facing changes in the national and international context. Their innovative activities are currently seen also as a process that results from various interactions among various actors. Each actor is characterized by its own role. Owner or investor provides sources for the realization of innovative activities and customers create demand. Synchronously, new information and communication technologies can reduce the disadvantages in all aspects of agricultural business. An important factor that can contribute to the increase of the innovation capacities of agricultural SMEs is the targeted policy with its objectives, approaches, and tools.

However, the realized studies showed various analyses without relation to specific aspects together. Authors often concentrated on one aspect without studying the relationships with others. We can find studies focused on innovation activities according to the sized category of SMEs, the innovation capacity of SMEs, their connection in various types of networking, internationalization processes, etc. This research aims to fill this gap by analyzing specific dimensions defined by elements that affect the innovation activity of SMEs toward their sustainable development, based on their specificities: type of SME, size category, and focus of business activities. The results point to the SMEs' perception of selected elements that affect innovative activities in relationships to their specificities. 


\section{ENTREPRENEURSHIP AND SUSTAINABILITY ISSUES}

ISSN 2345-0282 (online) http://jssidoi.org/jesi/

2020 Volume 8 Number 2 (December)

http://doi.org/10.9770/jesi.2020.8.2(68)

Make your research more visible, join the Twitter account of ENTREPRENEURSHIP AND SUSTAINABILITY ISSUES: @Entrepr69728810

The rest of the paper is structured as follows. As first, we defined three main dimensions that affect the innovative activities of agricultural SMEs toward sustainable development. Based on the literature review, we identified the main elements that belong to each dimension. In connection with specificities of agricultural SMEs (type, sized category, and focus of their business activities) we proposed three research hypotheses. The stated above is summarized in part 2. Literature review and Hypotheses Development. Part 3. Data and Methodology described used methodological approach. We described the sampling and we justified the use of statistical tests for the data evaluation. Part 3. Results and Discussion provide main results, which are compared with previous research works. The part Conclusion brings the final assessment, remarks, and main implications.

\section{Literature review and Hypotheses Development}

Various literature studies provide many dimensions that affected the innovative capability of SMEs. Pierre \& Fernandez (2018) observed fourteen dimensions of the innovation capacity of SMEs, from which six they considered highly relevant: network integrations, institutional support, innovation strategy and planning, innovation dedicated resources, access to cash flow and standards, and regulation. Martinez-Roman et al. (2011) identified three dimensions of the innovative capability: knowledge, organizational structure adapted of the development of the innovation and the human factor. Forsman (2011) identified seven dimensions in which manufacturing and service SMEs could achieve the capabilities for innovations: entrepreneurial capabilities, networking capabilities, utilization of knowledge, risk management capabilities, change management capabilities, business development capabilities, and customer and market knowledge. Lumpkin \& Dess (2001) evaluated two dimensions: proactiveness and competitive aggressiveness. In this research, we proposed three main dimensions for the next analysis: technological, non-technological, and organizational. Based on the literature review, we identified and sorted selected elements that represent each of the dimensions (Table 1).

Table 1. The dimensions defined by means of elements

\begin{tabular}{|c|c|c|}
\hline Technological dimension & Non-technological dimension & Organizational dimension \\
\hline T1 Technological processes & NT1 Marketing & O1 Qualification of employees \\
\hline $\begin{array}{l}\text { T2 Financial intensity of innovative } \\
\text { activities }\end{array}$ & \multirow{2}{*}{$\begin{array}{c}\text { NT2 The effectiveness of SMEs' } \\
\text { management }\end{array}$} & \multirow{2}{*}{ O2 The customers' demand } \\
\hline $\begin{array}{l}\text { T3 New techniques and equipment used to } \\
\text { produce goods or services }\end{array}$ & & \\
\hline
\end{tabular}

Source: own processing

Technological dimension relates to elements that nowadays spread to all areas of economic life in SMEs and covers: Technological processes (T1), Financial intensity of innovative activities (T2), and New techniques and equipment used to produce goods or services (T3).

The innovation generation process requires a number of factors such as a high level of technological capabilities, strong R\&D, and a pool of multidisciplinary skills (Mahemba \& Bruijn, 2003). According to Lazikova et al. (2018), the lack of innovativeness belongs to the internal factor that affects the achievement of SMEs' success. The more rapid technological and market changes foster an environment favorable to innovation (DeTienne\&Koberg, 2002; Čižo et al. 2020 a). The innovativeness may result in new technological processes. It is possible to increase the innovation ability of SMEs by providing quick and easy access to external sources of knowledge, new information, and communication technologies (ICT). This is connected with using various types of technological processes. Despite this fact, the application of new ICT tools in SMEs is still lagging behind (Corso, et al., 2003). 


\section{ENTREPRENEURSHIP AND SUSTAINABILITY ISSUES}

ISSN 2345-0282 (online) http://jssidoi.org/jesi/

2020 Volume 8 Number 2 (December)

http://doi.org/10.9770/jesi.2020.8.2(68)

Make your research more visible, join the Twitter account of ENTREPRENEURSHIP AND SUSTAINABILITY ISSUES: @Entrepr69728810

Technological processes (T1) are often connected mainly with technology-based firms (Rhee et al. 2010). In our research, we try to find out whether agricultural SMEs' perceived them as an important element for their innovativeness.

The ability to ensure the use of advanced technologies based on the most efficient innovation (Okuneviciute Neverauskiene et al., 2020) depends on financial capability and availability. Finance is a crucial determinant for innovation activities in enterprises, SMEs not excluded (Wonglimpiyarat, 2015); and financial constraints hold back innovation (Hyytinen \& Toivanen, 2005). Companies can increase the odds of introducing a new service or product successfully if they allocate more money to their innovation activities (Eggert et al., 2014; C`ižo et al. 2020 b). Many SMEs carrying out their activities in the agricultural sector have little education and limited exposure to financial instruments related to innovative activities, thus the aspects of the financial intensity of innovative activities (T2) belonged to the second element in the Technological dimension.

The third important element of the Technological dimension selected for analysis was (T3) New techniques and equipment used to produce goods or services. This element related mainly to issues of Industry 4.0, which is characterized by a blending of technologies that erase the boundaries between physical, digital, and biological spheres (Koraus at al. 2020). Innovative and latest technology improves productivity to a greater extent. Automation and information technology helps to achieve improvements in material handling, storage, communication system, and quality control (Kumar \& Suresh, 2006). The key to all these processes is human capital in terms of making, utilizing and upgrading changes related to Industry 4.0 (Ivanova et al., 2020).

Non- technological dimension consists of two elements that are necessary for the sustainable development of SMEs: Marketing (NT1) and the effective SMEs' management (NT2).

SMEs' innovation activities are the condition for their survival on the market (Benda-Prokeinová et al., 2017; Caurkubule et al. 2020) and they depend on the strategic orientation of SMEs. The quality of the business environment is often regarded as a major factor in the long-term economic competitiveness and sustainable development of SMEs (Grancay et al., 2015). Competitiveness is basically associated with the application of products in the domestic and foreign markets of organizations, integration groups, or countries to successful participation in the exchange of products of material or immaterial nature at different levels of trade (Simo et al., 2016). It might be well accepted nowadays that intensive competitiveness in terms of both quantity and quality makes it extremely difficult for a firm to differentiate itself from its competitors (Mura \& Kajzar, 2019). The market in which the SMEs offer their products or services can be a predictor of the effects of innovative activities. In terms of entering international markets, mainly the industrial production companies have the biggest interest in conducting business activities in international markets (Mura, 2019, Mura et al. 2017). SMEs often have to modify their products sold on the international market, not only from the reason that they aim to achieve outstanding business performance and competitive advantage but also to remain in the international market. According to Bozic \& Radas (2006), it is possible to expect that the more present an enterprise is in the international market; the more oriented its innovation activities are towards improving product quality, ecological and health aspects, as well as towards complying with legal standards and various regulations. International trade permits everybody to have more access to the goods and services that are created or performed around the world (Kordos, 2019). Due to the intense competition and constant changes, firms have to increase their innovative manners to maintain their competitive edge also through adaptation of marketing activities (NT1). Keskin (2006) in his research pointed also on the fact that developing and then implementing a marketing plan positively impacts firm innovativeness. Market-orientation in SMEs, driven by the feedbacks of customers, is a mechanistic and narrow form of innovation. SMEs are able to improve profitability by aptly matching customer responsiveness and market-driven pricing policy with product 


\section{ENTREPRENEURSHIP AND SUSTAINABILITY ISSUES}

ISSN 2345-0282 (online) http://jssidoi.org/jesi/

2020 Volume 8 Number 2 (December)

http://doi.org/10.9770/jesi.2020.8.2(68)

Make your research more visible, join the Twitter account of ENTREPRENEURSHIP AND SUSTAINABILITY ISSUES: @Entrepr69728810

innovation. Research on market orientation, to which the use of marketing tools is subordinated, may benefit from reframing existing models to incorporate innovation more directly (Salavou, 2002; Rak, Zrubak 2012; Korshenkov, Ignatyev, 2020).

The prerequisite for the successful application of innovative activities is also an effective management system in SMEs (NT2). Traditional management style based on centralized top-down decisions with many routines hinders problem-solving in innovative ways (Martinez-Roman et al., 2011). Managers (owners) in SMEs are responsible for the success of their business. They have to determine what actions to pursue at a given time. Uncertainty and the continually shifting situations at the market, pressure them to innovate. Managers (owners) in SMEs can make a better decision when there are fewer constraints imposed by an organization's context (DeTienne\&Koberg, 2002). Rhee et al. (2010) in their research stated, that top managers of small firms, therefore, are advised to pay full attention to improvements in innovativeness, with a particular emphasis on an ongoing learning practice, in their effort store superior business performance. SMEs have some limitation to the effective management due to their size, and teams that could solve the problems related to innovative activities can hinder the development of innovations. Most of them have a simple structure, which requires direct supervision.

The third dimension is the Organizational dimension. In our research, it narrows relates to the previous dimensions and elements and it concerns to organizational context in SMEs and consists of Qualification of employees (O1), and The customers' demand (O2).

It is characteristic for SMEs, that the small numbers of staff carry out a range of different functions, manage a small budget, and are occupied with survival and only partially solve the innovative activity. Faherty \& Stephens (2016) went deeper and dealt with the issues of the possibility to realize the innovative activities by microenterprises. They recommend simplifying the innovation, due to the fact, that the micro-enterprises regard innovation as a complicated activity that is associated with high-level technology research and development. Also, the learning orientation in SMEs has with a positive effect on the innovativeness of SMEs (Keskin, 2006) due to the fact that business advantages and opportunities emanating from the internally stored knowledge (Dvorský et al, 2019) and the human resources are considered as the cornerstone of the development (Jašková, 2019). Anderson and Boocock (2002) note that self-directed, work-based, and informal learning is dominant in small firms, as it allows increased flexibility and adaptability. Due to the stated above, the first important element in this dimension is the (O1) Qualification of employees. Firms meet the demand of their customers, through markets, by supplying products and services (Liao \& Rice, 2010).

When SMEs roll out new products and services, the required market knowledge should be obvious to them, as well as the understanding of how to communicate with costumers. Innovation refers to the generation and implementation of new market offerings that previously were unavailable to the firm's customer (Eggert et al., 2014). The quality of the product is established based on the customers' needs. The right quality is determined by the cost of the product and the technical characteristics as suited to the specific requirements (Kumar \& Suresh, 2006). Using customer information contributes to the innovation of SMEs (Keskin, 2006). They have key roles in developing product innovations (Forsman, 2011; Zeibote et al. 2019; Korauš et al. 2019). SMEs should use innovation in combination with a market orientation in order to achieve superior performance in terms of profitability (Salavou, 2002). Stated above requires to know, what is the customers' demand (O2).

In the view of the described context of three dimensions and their elements, we propose the following research hypotheses. There is a wide range of studies focused on innovation activities in various contexts observed in large 


\section{ENTREPRENEURSHIP AND SUSTAINABILITY ISSUES}

ISSN 2345-0282 (online) http://jssidoi.org/jesi/

2020 Volume 8 Number 2 (December)

http://doi.org/10.9770/jesi.2020.8.2(68)

Make your research more visible, join the Twitter account of ENTREPRENEURSHIP AND SUSTAINABILITY ISSUES: @Entrepr69728810

and SME enterprises, but there is a low number of studies focused on the family business. The study of this type of enterprise is limited by the data available from these enterprises, due to the fact, that the exact numbers of these enterprises are not stated in official registers. Within the first hypothesis, we compared the perception of the stated dimension by non-family SMEs and family SMEs. H1: There are statistically significant differences in the perceptions of stated elements related to innovative activities toward sustainable entrepreneurship between the non-family and family SMEs.

Similarly, the research studies are focused on the individual-sized category of SMEs or their comparison with other categories. This research provides a comparison of SMEs' perception among three main categories of SMEs by means of the second hypothesis. H2: There are statistically significant differences in the perceptions of stated elements related to innovative activities toward sustainable entrepreneurship among three sized categories of SMEs.

The last, third hypothesis is focused on SMEs' perception of stated dimensions according to the focus of business activities of their operation: H3 There are statistically significant differences in perceptions of stated elements related to innovative activities toward sustainable entrepreneurship of SMEs between SMEs that doing business in Slovak market and those in the international market.

\section{Data and Methodology}

To fulfill the main aim of the paper, the questionnaire surveys focused on issues of innovative activities of agricultural SMEs were realized. Data collection was carried out in 2019 within the Slovak regions. According to the Statistical Office of the Slovak Republic, there were 119540 SMEs in the Slovak economy in 2019, of which 3555 entities represented the agricultural SMEs. The estimation of range selection for the questionnaire survey from the number of agricultural SMEs was calculated according to formula (1) from Cochran (1977).

$$
\mathrm{n}=\frac{\mathrm{Z}^{2} * \mathrm{p} *(1-\mathrm{p})}{\mathrm{e}^{2}}
$$

Where: $\mathrm{n}$ is the requested sample size, $\mathrm{Z}$ - the $\mathrm{Z}$ value (e.g. 1.96 for $95 \%$ confidence level), $\mathrm{p}$ - the estimated proportion of an attribute that is present in the population (for this research the level of $\mathrm{p}$ was calculated using the share of agricultural SMEs in the total number of SMEs in the Slovak Republic), $d$ - desired level of precision and $e=3 \%$. We calculated that the requested research sample should be 123 SMEs. For the realization of questionnaires surveys with appropriate reliability and accuracy, the questionnaire surveys were distributed among 200 agricultural SMEs, from which 192 completed the questionnaire correctly.

Whole research sample (structure in Table 2) we sorted according to the type of enterprise (non-family SMEs and family SMEs), the sized category (according to the definition of OECD we used three categories of SMEs microenterprises (less than 10 employees), in which the turnover should not exceed EUR 2 million, small enterprises (10-49 employees), where the turnover should not exceed EUR 10 million and medium-sized enterprises (50-249 employees) turnover should not exceed EUR 50 million), the focus of business activities (Slovak market or international market). Due to the fact, that there is no official register of the family business in Slovakia, this research has a limitation in research sampling. The selection of respondents that belong to family SMEs was realized on the principle of snowball method (Heckathor, 2011). 


\section{ENTREPRENEURSHIP AND SUSTAINABILITY ISSUES}

ISSN 2345-0282 (online) http://jssidoi.org/jesi/

2020 Volume 8 Number 2 (December)

http://doi.org/10.9770/jesi.2020.8.2(68)

Make your research more visible, join the Twitter account of ENTREPRENEURSHIP AND SUSTAINABILITY ISSUES: @Entrepr69728810

From 192 of SMEs (Table 2), 38 (19.79\%) belonged to the family business. The highest number of respondents $(54.69 \%)$ in the case of size category of SMEs belonged to the category of micro-enterprises, from which $13.02 \%$ belonged to family SMEs. In the category of SMEs according to the placement of their conducted business activities, the highest number of SMEs (92.19\%) belonged to SMEs, which operate in Slovakia, of which 18.75\% belonged to family SMEs.

Table 2. The structure of research sample

\begin{tabular}{|l|l|l|l|l|l|l|l|}
\hline \multirow{2}{*}{ Category } & \multirow{2}{*}{ Type } & \multicolumn{2}{|l|}{ Non-family SMEs } & \multicolumn{2}{l|}{ Family SMEs } & \multicolumn{2}{|l|}{ Total } \\
\cline { 3 - 8 } & & $\mathbf{N}$ & $\mathbf{\%}$ & $\mathbf{N}$ & $\mathbf{\%}$ & $\mathbf{N}$ & $\mathbf{\%}$ \\
\hline \multirow{4}{*}{ Size category } & Micro & 80 & 41.67 & 25 & 13.02 & 105 & 54.69 \\
\cline { 2 - 8 } & Small & 61 & 31.77 & 11 & 5.73 & 72 & 37.50 \\
\cline { 2 - 8 } & Medium & 13 & 6.77 & 2 & 1.04 & 15 & 7.81 \\
\cline { 2 - 8 } Focus of business activities & Total & $\mathbf{1 5 4}$ & $\mathbf{8 0 . 2 1}$ & $\mathbf{3 8}$ & $\mathbf{1 9 . 7 9}$ & $\mathbf{1 9 2}$ & $\mathbf{1 0 0 . 0 0}$ \\
\hline & Slovak & 141 & 73.44 & 36 & 18.75 & 177 & 92.19 \\
\cline { 2 - 8 } & International & 13 & 6.77 & 2 & 1.04 & 15 & 7.81 \\
\cline { 2 - 8 } & Total & $\mathbf{1 5 4}$ & $\mathbf{8 0 . 2 1}$ & $\mathbf{3 8}$ & $\mathbf{1 9 . 7 9}$ & $\mathbf{1 9 2}$ & $\mathbf{1 0 0 . 0 0}$ \\
\hline
\end{tabular}

Source: own research

Respondents were asked to evaluate their perception of individual elements within stated three main dimensions that have an impact on their innovative activities toward sustainable development (Table 1). Stated elements were selected based on their importance toward the innovative activities of SMEs, as it is described in the previous part of this paper (2. Literature review and Hypotheses Development). SMEs' perception of elements that affect their innovative activities toward their sustainable development was realized through the assessment on six points scale from 0 - does not affect the innovation activity, 5 the mostly affect innovative activities.

The evaluation of obtained results was realized by using the descriptive statistics and parametric and non-parametric statistical tests. Using the statistical tests, we verified three hypotheses set out in section 2. Literature Review and Hypotheses Development. For the stated research hypotheses' evaluation, in the first step we utilized the tools of the descriptive statistics (relative frequency, mean, standard deviation, and median) of the respondents' answers. The second step consisted of the calculation of the Shapiro-Wilk test (SW), due to the fact that the using of parametric test (t-test and one way ANNOVA) depends on normally distribution of variables. If the calculated $\mathrm{p}$ value of SW test is higher than confidence level $(\mathrm{p}=0.05)$, the normality is not rejected and it is possible to use the parametric test. Otherwise, a non-parametric alternative to the t-test is used Mann Whitney U test (MWU), for the examination of differences between two independent variables, or Kruskal-Wallis test $(\mathrm{KW})$, to compare more than two independent variables (Balboni et al., 2013; Nachar, 2008). The results of the used test (SW, MWU, KW, and ANNOVA) were significant at $p \leq 0.05$ for all groups of SMEs. The results of these tests for each group of SMEs in the division stated above are provided in the next part of this research.

\section{Results and Discussion}

Table 3 presents the results of SMEs' perception of stated dimensions described by elements (Table 1) related to their innovative activities toward sustainable development, depending on the type of enterprise (non-family and family SMEs). The results showed that the most of non-family SMEs (27.08\%) as well as family SMEs (4.69\%) perceived as the most important element for their innovative activities the O1 - Qualification of employees (3.63 \pm 1.32 in case of non-family SMEs and 3.62 \pm 1.32 in case of family SMEs). The importance of these results corresponds to the research of Talebi \& Tajeddin (2001) who argued that SMEs, where the owners/ managers have 


\section{ENTREPRENEURSHIP AND SUSTAINABILITY ISSUES}

ISSN 2345-0282 (online) http://jssidoi.org/jesi/

2020 Volume 8 Number 2 (December)

http://doi.org/10.9770/jesi.2020.8.2(68)

Make your research more visible, join the Twitter account of ENTREPRENEURSHIP AND SUSTAINABILITY ISSUES: @Entrepr69728810

technical and vocational qualifications, are more likely, across the board, to innovate. Also, Demirbas et al. (2011) in their research confirmed the necessity of qualified personnel. According to them, firms, where the qualified personnel is missing, show a lower propensity to innovate, and thus, the innovation in a smaller manufacturing firm is unlikely to succeed.

In respect to the normality tests' results (the p-value of SW is lower than 0.05 in each case), to investigate for differences in each element between non-family and family SMEs, the MWU test was executed. As can be seen from Table 3, the MWU test confirms that these two groups of SMEs assigned the same importance to all investigated elements. We can accept the hypothesis H1.

Table 3. The perception of elements related to innovative activities by non-family and family SMEs (SMEs' answers, \%)

\begin{tabular}{|c|c|c|c|c|c|c|c|c|c|c|c|c|}
\hline Element & Category & $\mathbf{0}$ & 1 & 2 & 3 & 4 & 5 & Mean & SD & Median & SW & MWU \\
\hline \multirow{2}{*}{ T1 } & Non-family SMEs & 3.13 & 4.69 & 9.38 & 23.44 & 21.35 & 18.23 & 3.35 & 1.32 & 3.00 & 0.00 & \multirow{2}{*}{0.71} \\
\hline & Family SMEs & 1.04 & 0.52 & 3.13 & 5.73 & 5.73 & 3.65 & 3.36 & 1.30 & 3.00 & 0.00 & \\
\hline \multirow{2}{*}{$\mathbf{T} 2$} & Non-family SMEs & 6.77 & 15.10 & 20.31 & 21.88 & 10.42 & 5.73 & 2.36 & 1.34 & 2.00 & 0.00 & \multirow{2}{*}{0.77} \\
\hline & Family SMEs & 2.60 & 3.13 & 4.69 & 5.21 & 4.17 & 0.00 & 2.40 & 1.34 & 2.00 & 0.00 & \\
\hline \multirow{2}{*}{ T3 } & Non-family SMEs & 22.92 & 9.38 & 12.50 & 20.83 & 6.77 & 7.81 & 1.94 & 1.62 & 2.00 & 0.00 & \multirow{2}{*}{0.16} \\
\hline & Family SMEs & 5.21 & 5.73 & 3.13 & 4.69 & 0.00 & 1.04 & 1.89 & 1.61 & 1.00 & 0.00 & \\
\hline \multirow{2}{*}{ NT1 } & Non-family SMEs & 23.44 & 9.90 & 9.90 & 11.98 & 13.02 & 11.98 & 2.19 & 1.81 & 2.00 & 0.00 & \multirow{2}{*}{0.73} \\
\hline & Family SMEs & 5.73 & 2.08 & 2.08 & 5.73 & 2.60 & 1.56 & 2.28 & 1.83 & 2.50 & 0.00 & \\
\hline \multirow{2}{*}{ NT2 } & Non-family SMEs & 5.21 & 1.04 & 7.81 & 22.92 & 23.96 & 19.27 & 3.40 & 1.33 & 4.00 & 0.00 & \multirow{2}{*}{0.18} \\
\hline & Family SMEs & 0.52 & 2.60 & 1.56 & 5.73 & 7.29 & 2.08 & 3.40 & 1.29 & 3.00 & 0.00 & \\
\hline \multirow{2}{*}{01} & Non-family SMEs & 3.13 & 3.65 & 6.77 & 17.71 & 21.88 & 27.08 & 3.63 & 1.32 & 4.00 & 0.00 & \multirow{2}{*}{0.30} \\
\hline & Family SMEs & 0.00 & 1.56 & 1.56 & 6.77 & 5.21 & 4.69 & 3.62 & 1.32 & 3.50 & 0.00 & \\
\hline \multirow{2}{*}{$\mathbf{O 2}$} & Non-family SMEs & 6.77 & 5.21 & 9.38 & 23.96 & 17.19 & 17.71 & 3.14 & 1.45 & 3.00 & 0.00 & \multirow{2}{*}{0.63} \\
\hline & Family SMEs & 0.52 & 2.60 & 2.08 & 6.77 & 5.21 & 2.60 & 3.19 & 1.39 & 3.00 & 0.01 & \\
\hline
\end{tabular}

Source: own research and calculation in the program Statistica

Within the second hypothesis $(\mathrm{H} 2)$ we evaluated how the stated elements are perceived by micro, small and medium enterprises. For $18.74 \%$ of micro-enterprises as well as $11.46 \%$ of small enterprises, the most important element was O1 - Qualification of employees (3.64 \pm 1.37 in case of microenterprises and $3.64 \pm 1.30$ in case of small enterprises). For 2.08\% of medium-sized enterprises, the most important element was $\mathrm{T} 1$ - Technological processes (3.80 \pm 1.15$)$. We can notice that between the qualification of employees and technological processes conducted within SMEs is a close connection. Technological processes are an important part of innovation activities as well as in large enterprises as well as in SMEs. The problem with their implementation in SMEs narrow relates to limited human resources. An increase in system complexity, instead, acts in just the opposite way, as it determines the necessity of technological coordination between SMEs and their customers (Corso et al, 2003). Our results are consistent with the results of Rhee et al. (2010) who pointed on the connection between the learning orientation and proprietary technology in an innovative manner. According to them the learning orientation appears to have the potential to create intangible assets such as technology in an innovative manner.

Due to the results of normality's test $(p \leq 0.05)$ presented in the Table, in a way to investigate for differences in SMEs' perception among sized categories (micro, small and medium) in the perceived elements, the non-parametric test KW can be performed. In case if the p-value of normality's test is higher than 0.05 , the One-way ANNOVA was performed, because, this statistical technique requires that the variables should be normally distributed. The pvalue calculated for both tests showed, that if we compared the SMEs' perception of stated elements from the point 


\section{ENTREPRENEURSHIP AND SUSTAINABILITY ISSUES}

ISSN 2345-0282 (online) http://jssidoi.org/jesi/

2020 Volume 8 Number 2 (December)

http://doi.org/10.9770/jesi.2020.8.2(68)

Make your research more visible, join the Twitter account of ENTREPRENEURSHIP AND SUSTAINABILITY ISSUES: @Entrepr69728810

of view of their size category, there are no differences in perception of T1 and O1 among agricultural SMEs. Except for these elements there are no differences in perception of elements NT1 - Marketing, NT2 - The effectiveness of SMEs' management and the $\mathrm{O} 2$ - The customers' demand. The p-value of calculated tests was higher than the confidence level of 0.05 (see Table 4). The differences in SMEs' perception we observed in case of elements T2 Financial intensity of innovative activities $(\mathrm{p}=0.05)$ and T3 - New techniques and equipment used to produce goods or services $(\mathrm{p}=0.01)$. The T2 was the most important mainly for medium-sized enterprises $(3.07 \pm 1.39)$. The empirical evidence obtained within our research corroborates the results in the previous studies. Okuneviciute Neverauskiene et al. (2020) considered the financial situation as a factor of sustainable competitiveness. The financial results of enterprises could spur some of innovation investments (Liao \& Rice, 2010). Fundamental source for these activities is internal finance (Serrasqueiro et al., 2011), mainly based on profit (Belas et al., 2018). Fabus et al. (2019) highlighted the efficiency of financial decentralization mechanisms, which improve the innovation capability of firms through government support. Similarly, the T3 was the most important mainly for medium-sized enterprises (2.53 \pm 1.51$)$. It is related to the fact that the sustainable development of SMEs depends on the successful implementation of modern techniques, technologies and using the appropriate equipment. Nowadays, the Industry 4.0 comes to the forefront (Kordos, 2019), thus the traditional production process takes on a new dimension. SMEs need to respond to this trend if they want to keep their competitiveness and achieve sustainable development.

Table 4. The perception of elements related to innovative activities according size category of SMEs (SMEs' answers, \%)

\begin{tabular}{|c|c|c|c|c|c|c|c|c|c|c|c|c|c|}
\hline Element & Category & $\mathbf{0}$ & 1 & 2 & 3 & 4 & 5 & Total & Mean & SD & Median & SW & KW/ANNOVA \\
\hline \multirow{3}{*}{ T1 } & Micro & 3.13 & 3.13 & 7.29 & 16.15 & 10.94 & 14.06 & 54.69 & 3.30 & 1.43 & 3.00 & 0.00 & \multirow{3}{*}{0.99} \\
\hline & Small & 1.04 & 1.56 & 4.69 & 11.98 & 12.50 & 5.73 & 37.50 & 3.35 & 1.18 & 3.00 & 0.00 & \\
\hline & Medium & 0.00 & 0.52 & 0.52 & 1.04 & 3.65 & 2.08 & 7.81 & 3.80 & 1.15 & 4.00 & 0.01 & \\
\hline \multirow{3}{*}{$\mathbf{T 2}$} & Micro & 6.77 & 8.85 & 10.42 & 16.15 & 8.85 & 3.65 & 54.69 & 2.41 & 1.43 & 3.00 & 0.00 & \multirow{3}{*}{0.05} \\
\hline & Small & 2.60 & 8.33 & 12.50 & 9.38 & 4.17 & 0.52 & 37.50 & 2.15 & 1.15 & 2.00 & 0.00 & \\
\hline & Medium & 0.00 & 1.04 & 2.08 & 1.56 & 1.56 & 1.56 & 7.81 & 3.07 & 1.39 & 3.00 & 0.14 & \\
\hline \multirow{3}{*}{ T3 } & Micro & 19.27 & 9.90 & 7.29 & 12.50 & 1.56 & 4.17 & 19.27 & 1.63 & 1.58 & 1.00 & 0.00 & \multirow{3}{*}{0.01} \\
\hline & Small & 7.81 & 4.17 & 7.29 & 10.42 & 3.65 & 4.17 & 37.50 & 2.28 & 1.60 & 2.00 & 0.00 & \\
\hline & Medium & 1.04 & 1.04 & 1.04 & 2.60 & 1.56 & 0.52 & 7.81 & 2.53 & 1.51 & 3.00 & 0.27 & \\
\hline \multirow{3}{*}{ NT1 } & Micro & 20.31 & 4.69 & 6.77 & 10.94 & 5.21 & 6.77 & 54.69 & 1.93 & 1.81 & 2.00 & 0.00 & \multirow{3}{*}{0.11} \\
\hline & Small & 8.33 & 6.25 & 4.17 & 6.25 & 8.33 & 4.17 & 37.50 & 2.33 & 1.74 & 2.50 & 0.00 & \\
\hline & Medium & 0.52 & 1.04 & 1.04 & 0.52 & 2.08 & 2.60 & 7.81 & 3.33 & 1.72 & 4.00 & 0.02 & \\
\hline \multirow{3}{*}{ NT2 } & Micro & 4.69 & 3.13 & 5.73 & 13.02 & 15.10 & 13.02 & 54.69 & 3.28 & 1.51 & 4.00 & 0.00 & \multirow{3}{*}{0.51} \\
\hline & Small & 1.04 & 0.52 & 3.13 & 11.98 & 14.06 & 6.77 & 37.50 & 3.54 & 1.10 & 4.00 & 0.00 & \\
\hline & Medium & 0.00 & 0.00 & 0.52 & 3.65 & 2.08 & 1.56 & 7.81 & 3.60 & 0.91 & 3.00 & 0.02 & \\
\hline \multirow{3}{*}{01} & Micro & 2.08 & 2.60 & 5.73 & 10.94 & 14.58 & 18.75 & 54.69 & 3.64 & 1.37 & 4 & 0.00 & \multirow{3}{*}{0.88} \\
\hline & Small & 1.04 & 2.60 & 1.56 & 9.90 & 10.94 & 11.46 & 37.50 & 3.64 & 1.30 & 4 & 0.00 & \\
\hline & Medium & 0.00 & 0.00 & 1.04 & 3.65 & 1.56 & 1.56 & 7.81 & 3.47 & 0.99 & 3.00 & 0.03 & \\
\hline \multirow{3}{*}{$\mathbf{O 2}$} & Micro & 4.69 & 5.21 & 6.25 & 14.58 & 11.98 & 11.98 & 54.69 & 3.10 & 1.54 & 3.00 & 0.00 & \multirow{3}{*}{0.89} \\
\hline & Small & 2.60 & 2.08 & 4.17 & 13.54 & 8.85 & 6.25 & 37.50 & 3.14 & 1.37 & 3.00 & 0.00 & \\
\hline & Medium & 0.00 & 0.52 & 1.04 & 2.60 & 1.56 & 2.08 & 7.81 & 3.47 & 1.25 & 3.00 & 0.12 & \\
\hline
\end{tabular}

Source: own research and calculation in the program Statistica

In addition this paper indicates how the SMEs in depending on whether they carry out their activities on domestic or international market, perceived stated elements toward dimensions that have impact on their innovative activities toward sustainable development (H3). For $29.17 \%$ of SMEs with activities on domestic market, the most important element for the achievement of their innovativeness is the $\mathrm{O} 1$ - Qualification of employees (3.62 \pm 1.32$)$. The same 


\section{ENTREPRENEURSHIP AND SUSTAINABILITY ISSUES}

ISSN 2345-0282 (online) http://jssidoi.org/jesi/ 2020 Volume 8 Number 2 (December)

http://doi.org/10.9770/jesi.2020.8.2(68)

Make your research more visible, join the Twitter account of ENTREPRENEURSHIP AND SUSTAINABILITY ISSUES: @Entrepr69728810

element was the most important for $2.6 \%$ of SMEs which carry out their activities at the international market (3.73 \pm 1.33$)$.

As it can be seen from Table 5, this result is supported by the calculated p-value of MWU test and ANNOVA (pvalue is higher than significance level 0.05 in each of cases), which confirmed that these two groups of SMEs don't perceive the investigated elements differently. Several studies also confirmed the casual relationships between focus of business activities and innovativeness of SMEs (Lee \& Lee, 2007; Mahmoud et al., 2016; O'Cass \& Weerawardena, 2009). SMEs which are able to reflect on the pressure from the external as well as internal environment regardless to them conducted activities on domestic or foreign market, they are able to innovate. To achieve innovation, it is therefore essential to maintain adaptive behavior, which requires focus on market needs.

Table 5. The perception of elements related to innovative activities according focus of business activities of SMEs (SMEs' answers, \%)

\begin{tabular}{|c|c|c|c|c|c|c|c|c|c|c|c|c|}
\hline Element & Market focus & 0 & 1 & 2 & 3 & 4 & 5 & Mean & SD & Median & SW & MWU/t-test \\
\hline \multirow{2}{*}{$\mathrm{T} 1$} & Slovak & 3.13 & 5.21 & 11.98 & 27.08 & 24.48 & 20.31 & 3.36 & 1.30 & 3.00 & 0.00 & \multirow{2}{*}{0.96} \\
\hline & International & 1.04 & 0.00 & 0.52 & 2.08 & 2.60 & 1.56 & 3.27 & 1.58 & 4.00 & 0.02 & \\
\hline \multirow{2}{*}{$\mathrm{T} 2$} & Slovak & 8.85 & 17.71 & 22.92 & 25.52 & 12.50 & 4.69 & 2.32 & 1.33 & 2.00 & 0.00 & \multirow{2}{*}{0.09} \\
\hline & International & 0.52 & 0.52 & 2.08 & 1.56 & 2.08 & 1.04 & 2.93 & 1.44 & 3.00 & 0.40 & \\
\hline \multirow{2}{*}{$\mathrm{T} 3$} & Slovak & 26.04 & 13.54 & 13.54 & 25.00 & 5.21 & 8.85 & 1.96 & 1.63 & 2.00 & 0.00 & \multirow{2}{*}{0.66} \\
\hline & International & 2.08 & 1.56 & 2.08 & 0.52 & 1.56 & 0.00 & 1.73 & 1.49 & 2.00 & 0.04 & \\
\hline \multirow{2}{*}{ NT1 } & Slovak & 27.08 & 11.46 & 10.94 & 17.19 & 14.06 & 11.46 & 2.15 & 1.79 & 2.00 & 0.00 & \multirow{2}{*}{0.31} \\
\hline & International & 2.08 & 0.52 & 1.04 & 0.52 & 1.56 & 2.08 & 2.67 & 2.06 & 3.00 & 0.02 & \\
\hline \multirow{2}{*}{ NT2 } & Slovak & 5.21 & 3.13 & 8.33 & 27.08 & 29.17 & 19.27 & 3.41 & 1.32 & 4.00 & 0.00 & \multirow{2}{*}{0.84} \\
\hline & International & 0.52 & 0.52 & 1.04 & 1.56 & 2.08 & 2.08 & 3.33 & 1.54 & 4.00 & 0.09 & \\
\hline \multirow{2}{*}{$\mathrm{O} 1$} & Slovak & 2.60 & 5.21 & 8.33 & 21.88 & 25.00 & 29.17 & 3.62 & 1.32 & 4.00 & 0.00 & \multirow{2}{*}{0.74} \\
\hline & International & 0.52 & 0.00 & 0.00 & 2.60 & 2.08 & 2.60 & 3.73 & 1.33 & 4.00 & 0.00 & \\
\hline \multirow{2}{*}{$\mathrm{O} 2$} & Slovak & 6.25 & 7.29 & 10.94 & 27.60 & 21.35 & 18.75 & 3.16 & 1.44 & 3.00 & 0.00 & \multirow{2}{*}{0.57} \\
\hline & International & 1.04 & 0.52 & 0.52 & 3.13 & 1.04 & 1.56 & 2.93 & 1.62 & 3.00 & 0.07 & \\
\hline
\end{tabular}

Source: own research and calculation in the program Statistica

\section{Conclusions}

The results of our research showed that innovative activities of SMEs are affected by three stated dimensions: technological, non-technological, and organizational. Within these dimensions, we identified three main highly rated elements that SMEs considered as the most important for the realization of innovative activities in their business toward sustainable development (see also in Figure 1). 
Make your research more visible, join the Twitter account of ENTREPRENEURSHIP AND SUSTAINABILITY ISSUES: @Entrepr69728810

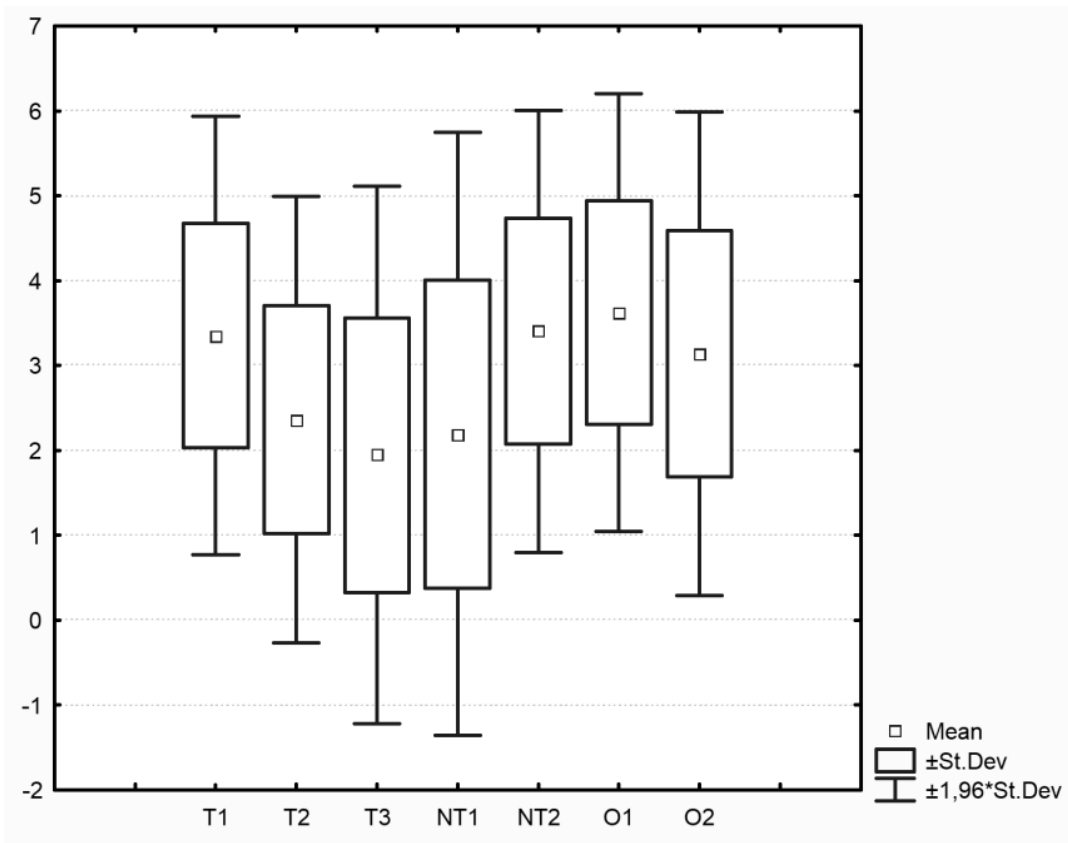

Figure 1. Descriptive statistics of observed elements.

Source: own research

The most important element according SMEs was the (O1) Qualification of employees (3.62 \pm 1.32$)$ This result builds on other studies (Keskin, 2006; Mahmoud et al., 2016; Rhee et al., 2010; Talebi \& Tajeddin, 2011 and many others) that have confirmed the importance of skills, qualification, learning orientation and training in SMEs towards increasing of their innovation activities. As confirmed by Polakovic et al. (2015) the education for managers and owners of SMEs is important due to the fact, that they usually get education in order to get soft and hard skills, which are necessary for achieving the required performance of the organization.

Second important element according to the SMEs' perception was (NT2) The effectiveness of SMEs' management

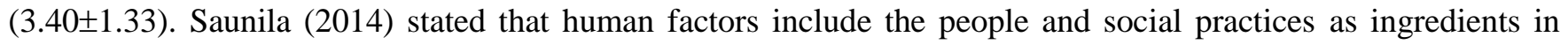
organizational success, on which the innovative activities depend. In regard to achieving the innovative activities at the required level, it is necessary to have person/s in firm, responsible for finding the firms' innovative capabilities. Due to the fact, that innovation activity involves the whole organization and conditions of the organizational behavior.

Third, the highly rated element was (T1) Technological processes (3.35 \pm 1.32$)$ and and cyber-security strategies. They consist of the ordered sequence of steps that must be followed in order to achieve the innovations. Technology is one of the enablers of innovation (Mambula, 2002). The Industry 4.0 approach permitted the creation of such an environment in which all elements are continuously and effortlessly linked together. The platform of Industry 4.0 could provide also for agricultural SMEs the innovative background. On the opposite side, SMEs' innovative activities are affected by obstacles in the innovativeness processes due to the fast development of technologies (Zambon et al., 2019), financing these activities, etc. Some of the research studies showed the tendency of SMEs 


\section{ENTREPRENEURSHIP AND SUSTAINABILITY ISSUES}

ISSN 2345-0282 (online) http://jssidoi.org/jesi/

2020 Volume 8 Number 2 (December)

http://doi.org/10.9770/jesi.2020.8.2(68)

Make your research more visible, join the Twitter account of ENTREPRENEURSHIP AND SUSTAINABILITY ISSUES: @Entrepr69728810

to adopt soft technologies as the operating methods, improvements in production processes, methods, organization and the market (Mahemba \& Bruijn, 2003; Mambula, 2002)

The understanding of innovation in SMEs has an important economic implication. The innovative activities of SMEs are affected by various elements. This paper provides the results of SMEs' perception of those elements that were in the previous research studies identified as fundamental for SMEs' future development toward sustainability.

As the COVID-19 pandemic continues to create long-term demands for remote work and more online activity, SMEs' must be vigilant in not only maintaining their cyber-security strategies but also in being proactive to prevent cyber attacks and address any possible vulnerabilities before they pose a problem. One of the most important lessons we all are learning during this pandemic is that we are stronger and more successful when we work together, and that is clear in the steps we must take to protect our businesses and to educate the public in proper cyber security.

\section{References}

Anderson, V., \& Boocock, G. (2002). Small firms and internationalisation: learning to manage and managing to learn. Human Resource Management Journal, 12(3), 5-24. https://doi.org/10.1111/j.1748-8583.2002.tb00068.x

Balboni, B., Bortoluzzi, G., \& Grandinetti, R. (2013). On the relationship between size, capabilities and internationalisation: an explorative analysis of Italian subcontracting SMEs. International Journal of Globalisation and Small Business, 5(1-2), 114-132. https://doi.org/10.1504/IJGSB.2013.050489

Berne, DF., Coda, R. \& Krakauer, P. (2019). The innovation challenge in micro and small enterprises (MSE). Innovation \& Management Review. 16 (3), 235-252. https://doi.org/10.1108/INMR-03-2019-0031

Benda-Prokeinová, R., Dobeš, K., Mura, L., Buleca, J. 2017. Engel's Approach as a tool for estimating consumer behaviour. E \& M Ekonomie a Management, 20 (2), 15 - 29 doi: 10.15240/tul/001/2017-2-002

Bozic, L., \& Radas, S. (2006). The effects of Innovation activities in SMEs in the Republic of Croatia. Croatian economic survey, Issue 8., 33-52. Retrieved April 2020, from https://hrcak.srce.hr/index.php?show=clanak\&id_clanak_jezik=9600

Caiazza, R., Volpe, T., \& Stanton, JL. (2016). "Guest editorial", Innovation in the agro-food value chain. British Food Journal, 118 (6), $1282-$ 1291. https://doi.org/10.1108/BFJ-03-2016-0129

Ciliberti, S., Carraresi, L., \& Bröring, S. (2016). Drivers of innovation in Italy: food versus pharmaceutical industry. British Food Journal, 118(6), 1292-1316. https://doi.org/10.1108/BFJ-10-2015-0405

Čižo, E., Lavrinenko, O., Ignatjeva, S. 2020 a. Analysis of the relationship between financial development and economic growth in the EU countries. Insights into Regional Development, 2(3), 645-660. https://doi.org/10.9770/IRD.2020.2.3(3)

Čizo, E., Ignatjeva, S., Lavrinenko, O. 2020 b. Determinants of financial development of the EU countries in the period 1995-2017. Insights into Regional Development, 2(2), 505-522. https://doi.org/10.9770/IRD.2020.2.2(1)

Cochran WG. (1977). Sampling Techniques. New York: Wiley and Sons.

Corso, M., Martini, A., Paolucci, E., \& Pellegrini, L. (2003). Knowledge management configurations in Italian small to medium enterprises. Integrated Manufacturing Systems, 14(1), 45-56. https://doi.org/10.1108/09576060310453344

Caurkubule, Zh. L., Kenzhin, Zh. B. Bekniyazova, D.S., Bayandina, G.D., Dyussembekova, G. S. 2020. Assessment of competitiveness of regions of the Republic of Kazakhstan. Insights into Regional Development, 2(1), 469-479. http://doi.org/10.9770/IRD.2020.2.1(6) 


\section{ENTREPRENEURSHIP AND SUSTAINABILITY ISSUES}

ISSN 2345-0282 (online) http://jssidoi.org/jesi/

2020 Volume 8 Number 2 (December)

http://doi.org/10.9770/jesi.2020.8.2(68)

Make your research more visible, join the Twitter account of ENTREPRENEURSHIP AND SUSTAINABILITY ISSUES: @Entrepr69728810

Demirbas, D., Hussain, J. G., \& Matlay, H. (2011). Owner-managers' perceptions of barriers to innovation: empirical evidence from Turkish SMEs. Journal of Small Business and Enterprise Development, 18 (4), 764-780. https://doi.org/10.1108/14626001111179794

DeTienne, D. R., \& Koberg, C. S. (2002). The impact of environmental and organizational factors on discontinuous innovation within hightechnology industries. IEEE Transactions on engineering management. 49(4), 352-364. https://doi.org/10.1109/TEM.2002.806719

Dvorský, J., Petráková, Z., Polách, J. (2019). Assessing the Market, Financial, and Economic Risk Sources by Czech and Slovak SMEs. International Journal of Entrepreneurial Knowledge, 7(2), 30-40. doi:10.12345-0008

Eggert, A., Thiesbrummel, C., \& Deutscher, C. (2014). Differential effects of product and service innovations on the financial performance of industrial firms. Journal of Business Market Management, 7(3), 380-405. Retrieved April, 15, 2020 from http://www.jbmonline.net/index.php/jbm/article/view/80

Fabus, M., Dubrovina, N., Guryanova, L., Chernova, N. \& Zyma, O. (2019). Strengthening financial decentralization: driver or risk factor for sustainable socio-economic development of territories. Entrepreneurship and Sustainability Issues, 7(2), 875-890. http://doi.org/10.9770/jesi.2019.7.2(6)

Faherty, U., \& Stephens, S. (2016). Innovation in micro enterprises: reality or fiction? Journal of small business and enterprise development, 23 (2), 349-362. https://doi.org/10.1108/JSBED-11-2013-0176

Forsman, H. (2011). Innovation capacity and innovation development in small enterprises. A comparison between the manufacturing and service sectors. Research policy, 40(5), 739-750.

Grancay, M., Grancay, N., Drutarovska, J., Mura, L. 2015. Gravity model of trade of the Czech and Slovak Republics 1995-2012: How have determinants of trade changed. Politicka Ekonomie, 63 (6), 759-777.

Heckathorn, DD. (2011). Comment: Snowball versus respondent-driven sampling. Sociological methodology, 41(1), 355-366. https://doi.org/10.1111/j.1467-9531.2011.01244.x

Hyytinen, A., \& Toivanen, O. (2005). Do financial constraints hold back innovation and growth?: Evidence on the role of public policy. Research Policy, 34(9), 1385-1403. https://doi.org/10.1016/j.respol.2005.06.004

Ivanova, E., Masarova, J., Koisova, E. (2020). Evaluation of the level of development of digital economy and digital skills in Slovak Republic and Czech Republic. In Kordos, M. (Ed.) Interntational Scientific Conference on the Impact of Industry 4.0 on Job Creation, pp. 167-175. Trenčianske Teplice: Alexander Dubček University of Trenčín (Slovakia).

Jašková, D. (2019). Assessment of social development in Slovakia in the context of human resources. Central European Journal of Labour Law and Personnel Management, 2 (2), 21-32. ISSN 2644-4917. https://doi.org/10.33382/cejllpm.2019.03.02

Keskin, H. (2006). Market orientation, learning orientation, and innovation capabilities in SMEs An extended model. European Journal of Innovation Management, 9(4), 396-417. https://doi.org/10.1108/14601060610707849

Kordos, M. (2019). The synergies of USA foreign trade policy agenda challenges within the Industry 4.0. AD ALTA - Journal of interdisciplinary research, 9(1), 137-142

Korauš, A., Gombár, M., Kelemen, P. \& Backa, S. (2019). Awareness of security risks associated with payment systems analyzed by the methods of multidimensional statistics. Journal of Security and Sustainability Issues, 8(4), 687-703. https://doi.org/10.9770/jssi.2019.8.4(12)

Korauš, A., Kaščáková, Z., Felcan, M. (2020). The impact of ability-enhancing HRM practices on perceived individual performance in IT industry in Slovakia. Central European Journal of Labour Law and Personnel Management, 3(1), 33-45. doi: 10.33382/cejllpm.2020.04.03

Korshenkov, E., Ignatyev, S. 2020. Empirical interpretation and measurement of the productivity and efficiency of regions: The case of Latvia. Insights into Regional Development, 2(2), 549-561. https://doi.org/10.9770/IRD.2020.2.2(4)

Kumar, S. A., \& Suresh, N. (2006). Production and operations management. New Delhi: New Age International (P) Limited, Publishers. 


\section{ENTREPRENEURSHIP AND SUSTAINABILITY ISSUES}

ISSN 2345-0282 (online) http://jssidoi.org/jesi/

2020 Volume 8 Number 2 (December)

http://doi.org/10.9770/jesi.2020.8.2(68)

Make your research more visible, join the Twitter account of ENTREPRENEURSHIP AND SUSTAINABILITY ISSUES: @Entrepr69728810

Lazikova, J., Bandlerova, A., Rohacikova, O., Schwarcz, P., Rumanovska, L. (2018). Regional Disparities of Small and Medium Enterprises in Slovakia. Acta Polytechnica Hungarica, 15(8), 227-246. https://doi.org/10.12700/APH.15.8.2018.8.12

Liao, T. S., \& Rice, J. (2010). Innovation investments, market engagement and financial performance: A study among Australian manufacturing SMEs. Research Policy, 39(1), 117-125. https://doi.org/10.1016/j.respol.2009.11.002

Lee, C. \& Lee, CG. (2007). SME innovation in the Malaysian manufacturing sector. Economics Bulletin, 12 (30), 1-12. Retrieved April, 10, 2020 from https://ro.uow.edu.au/cgi/viewcontent.cgi?referer=https://scholar.google.sk/\&httpsredir=1\&article=4159\&context= commpapers

Lumpkin, G. T., \& Dess, G. G. (2001). Linking two dimensions of entrepreneurial orientation to firm performance: The moderating role of environment and industry life cycle. Journal of Business Venturing, 16(5), 429-451. https://doi.org/10.1016/S0883-9026(00)00048-3

Mahemba, C. M., \& Bruijn, E. J. D. (2003). Innovation activities by small and medium sized manufacturing enterprises in Tanzania. Creativity and innovation management, 12(3), 162-173. https://doi.org/10.1111/1467-8691.00279

Mahmoud, M. A., Blankson, C., Owusu-Frimpong, N., Nwankwo, S., \& Trang, T. P. (2016). Market orientation, learning orientation and business performance. International Journal of Bank Marketing, 34(5), 623-648. https://doi.org/10.1108/IJBM-04-2015-0057.

Mambula, C. (2002). Perceptions of SME growth constraints in Nigeria. Journal of Small Business Management, 40(1), 58-65. https://doi.org/10.1111/1540-627X.00039

Martinez-Roman, J. A., Gamero, J., \& Tamayo, J. A. (2011). Analysis of innovation in SMEs using an innovative capability-based non-linear model: A study in the province of Seville (Spain). Technovation, 31(9), 459-475. https://doi.org/ 10.1016/j.technovation.2011.05.005

Mura, L. (2019). Entrepreneurship internationalization - Case of Slovak family businesses. AD ALTA-Journal of Interdisciplinary Research, $9(1), 222-226$.

Mura, L., Havierniková, K, Machová, R. 2017. Empirical results of entrepreneurs' network: Case study of Slovakia. Serbian Journal of Management, 12(1), 121-131

Mura, L., Kajzar, P. (2019). Small Businesses in Cultural Tourism in a Central European Country. Journal of Tourism and Services, 10(19), 40-54. https://doi.org/10.29036/jots.v10i19.110

Nachar, N. (2008). The Mann-Whitney U: A test for assessing whether two independent samples come from the same distribution. Tutorials in quantitative Methods for Psychology, 4(1), 13-20. https://doi.org/10.20982/tqmp.04.1.p013

O'Cass, A., \& Weerawardena, J. (2009). Examining the role of international entrepreneurship, innovation and international market performance in SME internationalisation. European Journal of Marketing, 43 (11-12), 1325-1348. https://doi.org/10.1108/0309056 0910989911

Okuneviciute Neverauskiene, L., Danileviciene, I., \& Tvaronaviciene, M. (2020). Assessment of the factors influencing competitiveness fostering the country's sustainability. Economic Research-Ekonomska Istraživanja, 33(1), 1909-1924.

Pierre, A., \& Fernandez, A-S. (2018). Going deeper into SMEs' innovation capacity: and empirical exploration of innovation capacity factors. Journal of Innovation Economics \& Management, Issue 25, pp. 139-181. https://doi.org/10.3917/jie.pr1.0019

Polakovic, P., Fabus, M., Gasperova, J., \& Slovakova, I. (2015). The effective use of information technologies in education and management of current managers. In Bittmanova, B. and Vlkova, E. (Eds.), International Relations 2015: Current Issues of world economy and politics, Proceedings paper (pp. 585- 594). Smolenice (Slovakia): University of Economics in Bratislava.

Raghuvanshi, J., Agrawal, R., \& Ghosh, PK.. (2019). Measuring the innovation capability of micro enterprises in India. Benchmarking: An International Journal, 26(5), 1405-1430. https://doi.org/10.1108/BIJ-08-2018-0229

Rak, R,, Zrubak, R. (2012). Project eCALL - Car in Emergency Situation. 7th Scientific International Conference Crisis Management: Envirenmental Protection of Population - Conference Proceedings. Edited by Horak, R; Juricek, L., Schwarz, R. pp. 251-258, Proceedings paper, ISBN 978-80-86710-57-0. 
Make your research more visible, join the Twitter account of ENTREPRENEURSHIP AND SUSTAINABILITY ISSUES: @Entrepr69728810

Rhee, J., Park, T.; Lee, D. H. (2010). Drivers of innovativeness and performance for innovative SMEs in South Korea: Mediation of learning orientation. Technovation, 30(1), 65-75. https://doi.org/10.1016/j.technovation.2009.04.008

Salavou, H. (2002). Profitability in market-oriented SMEs: does product innovation matter? European Journal of Innovation Management, 5(3), 164-171. https://doi.org/10.1108/14601060210436736

Saunila, M. (2014). Innovation capability for SME success: perspectives of financial and operational performance. Journal of Advances in Management Research, 11(2), 163-175. https://doi.org/10.1108/JAMR-11-2013-0063

Serrasqueiro, Z., Maçãs Nunes, P., \& Leitão, J. (2011). Sources of finance for R\&D investment: Empirical evidence from Portuguese SMEs using dynamic estimators. Innovation - Organization and Management, 13(2), 187-206. https://doi.org/10.5172/impp.2011.13.2.187

Simo, D., Mura, L., Buleca, J. (2016). Assessment of milk production competitiveness of the Slovak Republic within the EU-27 countries. Agricultural Economics-Zemedelska Ekonomika, 62(10), 482-492. https://doi.org/10.17221/270/2015-AGRICECON

Talebi, K., \& Tajeddin, M. (2011). The adoption of new and innovative knowledge by small and medium enterprises of Iran: Opportunities and constraints for growth. African Journal of Business Management, 5(1), 39-49. https://doi.org/10.5897/AJBM10.366

Wonglimpiyarat, J. (2015). Challenges of SMEs innovation and entrepreneurial financing. World Journal of Entrepreneurship, Management and Sustainable Development, 11(4), 295-311. https://doi.org/10.1108/WJEMSD-04-2015-0019

Zambon, I., Cecchini, M., Egidi, G., Saporito, MG., \& Colatoni, A. (2019). Revolution 4.0: Industry vs. Agriculture in a Future Development for SMEs. Processes, 7(1), article number 36. https://doi.org/10.3390/pr7010036

Zeibote, Z., Volkova, T., Todorov, K. 2019. The impact of globalization on regional development and competitiveness: cases of selected regions, Insights into Regional Development, 1(1), 33-47. https://doi.org/10.9770/ird.2019.1.1(3)

\section{Acknowledgements}

The contribution is the result of Vega project no. 1/0194/19 "Research on process-oriented management of financial management focusing on detection of tax evasion in terms of international business".
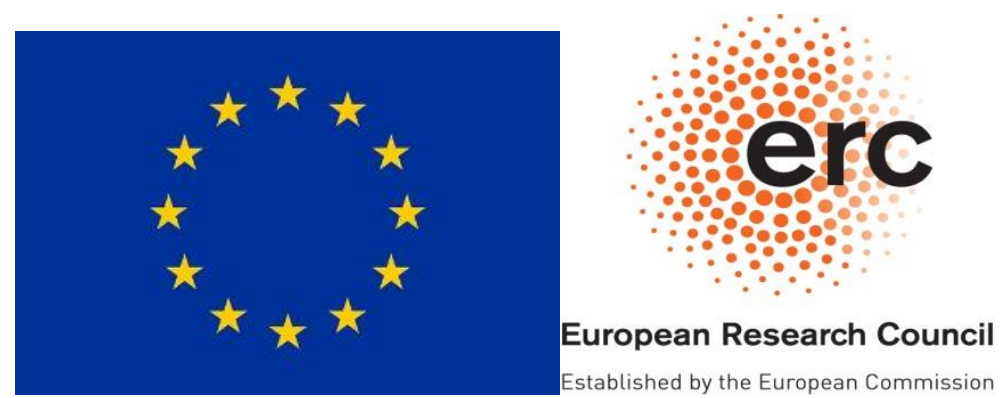


\section{ENTREPRENEURSHIP AND SUSTAINABILITY ISSUES}

ISSN 2345-0282 (online) http://jssidoi.org/jesi/

2020 Volume 8 Number 2 (December)

http://doi.org/10.9770/jesi.2020.8.2(68)

Make your research more visible, join the Twitter account of ENTREPRENEURSHIP AND SUSTAINABILITY ISSUES: @Entrepr69728810

Prof. Ing. Antonín KORAUŠ, PhD., LL.M., MBA is professor at Academy of the Police Force in Bratislava, Slovak Republic. Research interests: economy security, finance security, cyber security, energy security, finance, banking, management, AML, economic frauds, financial frauds, marketing, sustainability.

ORCID ID: https://orcid.org/0000-0003-2384-9106

Katarína HAVIERNIKOVÁ, PhD., is an Assistant Professor at the Faculty of Social and Economic Relations, Alexander Dubček Univesity in Trenčín, Slovakia. Her research interest is focused on issues of small and medium - sized enterprises, entrepreneurial intention, industrial clusters, risk management and regional development. During her pedagogical and research activities she has been involved in work on scientific research projects of faculty and departmental character as an effective project leader, deputy head of the project, co-worker. She publishes a series of publications, both in domestic and international periodicals, journals and scientific monograhps.

ORCID ID: https://orcid.org/0000-0002-9019-8684

Assoc. Prof. Ing. Miroslav GOMBÁR, PhD. is an associate professor in the Department of Management, Faculty of Management at the University of Prešov in Prešov since 2016. Since 2016, he works as head of the Department of Management, and teaches school subjects: statistics, management, operations management, and logistics.

ORCID ID: $\underline{\text { https://orcid.org/0000-0002-8383-7820 }}$

Filip ČERNÁK, Ph. D. Candidate at the Faculty of Management at the University of Prešov in Prešov, Slovak Republic ORCID ID: https://orcid.org/0000-0001-7812-9371

Miroslav FELCAN is an associate professor at Academy of the Police Force in Bratislava, Slovak Republic. Research interests: administrative law, tax law, financial law, finance security, economic frauds, financial frauds, sustainability.

ORCID ID: $\underline{\text { https://orcid.org/0000-0002-4274-4417 }}$

Copyright (C) 2020 by author(s) and VsI Entrepreneurship and Sustainability Center

This work is licensed under the Creative Commons Attribution International License (CC BY).

http://creativecommons.org/licenses/by/4.0/

(c) (†) Open Access 